\title{
Effect of Nitrogen Fertilizer Rates and Intra Row Spacing on Bulb Yield of Onion (Allium cepa L.) at Shire, Northern Ethiopia
}

\author{
Kiros Gebretsadik ${ }^{1}$, Nigussie Dechassa ${ }^{2}$ \\ ${ }^{1}$ Department of Plant Sciences, Aksum University, Shire Campus P.o.box 314 Shire, Ethiopia \\ ${ }^{2}$ Department of Plant Sciences, Haramaya University P.o.box 138 Dire Dawa, Ethiopia
}

\begin{abstract}
A field experiment was conducted to study the effect of nitrogen $(N)$ fertilizer rates and intra row spacing on yield of onion (Allium cepa L.) cultivar Bombay Red. Treatments consisted of a factorial combination of four rates of $N\left(0,50,100\right.$ and $\left.150 \mathrm{~kg} \mathrm{~N} \mathrm{ha}^{-1}\right)$ and four intra row spacing $(4,6,8$, and $10 \mathrm{~cm})$ with inter row spacing of $20 \mathrm{~cm}$. The experiment was laid out as a Randomized Complete Block Design with three replications. The analysis of variance revealed that the main effects of $N$ and intra row spacing significantly affected average fresh bulb weight, bulb diameter, marketable yield, and total bulb yield. $100 \mathrm{~kg} \mathrm{~N} \mathrm{ha-1}$ was found the best rate of $N$ to get optimum marketable bulb yield (31.455 $\left.\mathrm{t} \mathrm{ha}^{-1}\right)$, total bulb yield $\left(32.84 \mathrm{th \textrm {h } ^ { - 1 }}\right)$ and average bulb weight $(86.50 \mathrm{~g})$. The results also revealed that intra row spacing of $6 \mathrm{~cm}$ was optimum. Combined Spacing of $6 \mathrm{~cm}$ x $20 \mathrm{~cm}$ with $100 \mathrm{~kg} \mathrm{~N}$ ha is most favourable for onion cultivar Bombay Red production at Shire, northern Ethiopia.
\end{abstract}

Keywords: Nitrogen fertilizer, Intra row spacing, Onion, bulb yield

\section{Introduction}

Onion (Allium cepa L.) is a vegetable crop grown for its pungent bulbs and flavourful leaves. It belongs to the genus Allium of the family Amaryllidaceae [1]. Generally, all plant parts of alliums can be consumed by humans except perhaps the seeds [2]. Onions have significant contributions to the nutritional requirements of human beings and have also medicinal values and are primarily consumed for their unique flavour or for their ability to enhance the flavour of other foods [3].

Onion and/or shallot are probably cultivated in all countries of tropical Africa including Ethiopia [4]. Onion is important in the daily Ethiopian diet, cultivated both under rain fed and irrigated conditions. In 2010/11 during the rainy season 22,035.8 ha of land was planted and about 2.37 million tons of bulbs were obtained with an average yield of $10.75 \mathrm{t} \mathrm{ha}^{-1}$ [5] which is low compared to other onion producing countries like the Republic of Korea (66.15 t ha-1), USA (56.13 t ha ${ }^{-1}$ ), the Netherlands (51.64 t ha-1), Japan (46.64 t $\mathrm{ha}^{-1}$ ) and Egypt (36.16 t ha ${ }^{-1}$ ) in the production year of 2011 [6].

One of the major bottlenecks of onion production in Ethiopia particularly at Shire area is improper agronomic practices used by farmers. The optimum level of any agronomic practices such as plant population density and fertilizer application varies with the environment, purpose of the crop and variety. To optimize onion productivity a full package of information is required for specific growing system [7], [8]. The use of optimum plant population density has a dual advantage. It avoids strong competition between plants for growth factors such as water, nutrients, and light. Conversely, it enables efficient use of available crop land without wastage [9].
Spacing of $10 \mathrm{~cm}$ between two adjacent plants and $30 \mathrm{~cm}$ between rows was recommended when transplanting onions to permanent fields [10]. However, this spacing is not optimum under all conditions of growth as well as crop or varietal characteristics. Varieties of onion may differ in root architecture, foliage and other growth characteristics. A cultivar performs differently under different agro climatic conditions and various cultivars of the same species grown even in the same environment often yield differently [11].

Performance of a cultivar mainly depends on the interaction of genetic makeup and the environment [12] reported that the recommended spacing for improved onion production in Ethiopia is $10 \mathrm{~cm} \times 20 \mathrm{~cm} \times 40 \mathrm{~cm}$ spacing where $10 \mathrm{~cm}$ is the spacing between plants, $20 \mathrm{~cm}$ is the spacing between rows and $40 \mathrm{~cm}$ is the width of plant bed including irrigation water path used for watering the plant. However, this recommendation was given irrespective of onion cultivars and only for furrow irrigation system. There is scanty of information on appropriate plant spacing for rain fed onion production in the study area.

Ethiopian Institute of Agricultural Research [13] recommended $100 \mathrm{~kg}$ DAP ha ${ }^{-1}$ and $150 \mathrm{~kg}$ urea $\mathrm{ha}^{-1}$ for onion production with no indication and consideration of appropriate spacing, cultivar, soil type and environmental conditions. Whereas, [14] suggested $200 \mathrm{~kg}$ DAP and 100 $\mathrm{kg}$ Urea in sandy loam soils of Ethiopia was recommended. Hence, there is lack of improved techniques of fertilizer rates in onion production in northern Ethiopia particularly in the study area. This research is, therefore, initiated with the objective to determine the influences of intra row spacing and nitrogen fertilizer on bulb yield of onion. 


\section{International Journal of Science and Research (IJSR)}

ISSN (Online): 2319-7064

Index Copernicus Value (2013): 6.14 | Impact Factor (2015): 6.391

\section{Materials and Methods}

\subsection{Description of the study site}

The experiment was conducted at the Well Foundation Farmers' Training Centre at Shire Tigray Region, northern Ethiopia. It is located at an altitude of $1900 \mathrm{~m}$ above sea level [15]. The site is situated at latitude of $14^{\circ} 6^{\prime} \mathrm{N}$ and longitude of $38^{\circ} 17^{\prime} \mathrm{E}$. The mean annual rainfall is $990 \mathrm{~mm}$ and average annual minimum and maximum temperatures are $12.4^{\circ} \mathrm{C}$ and $28.5^{\circ} \mathrm{C}$, respectively. The rainy season extends from May to September and the maximum rain is received in the months of June to August. The field has sandy clay loam soil with $\mathrm{pH}$ of 6.57 , organic carbon $1.29 \%$, total nitrogen $0.08 \%$, available $\mathrm{P}$ of 43.62 parts per million, exchangeable $\mathrm{K}$ of $1.55 \mathrm{cmol}^{(+)} \mathrm{kg}^{-1}$ and CEC of 14.93 $\mathrm{cmol} \mathrm{kg}^{-1}$ soil. The rural area around the study site is known for the mixed crop-livestock farming system [16].

\subsection{Treatments and experimental design}

The treatments consisted of four intra row spacing $(4,6,8$, and $10 \mathrm{~cm}$ ) with the same inter row spacing of $20 \mathrm{~cm}$ and four levels of nitrogen $\left(0,50,100\right.$ and $\left.150 \mathrm{~kg} \mathrm{~N} \mathrm{ha}^{-1}\right)$ laid out as a randomized complete block design (RCBD) in a $4 \mathrm{x}$ 4 factorial arrangement and replicated three times.

Seeds were sown in a nursery on a well prepared seed bed. Fifty five days after sowing, seedlings with three to four green true leaves were transplanted to the experimental field. Only vigorous and healthy seedlings were transplanted. Nitrogen was applied at the specified rates in three splits $\left(1 / 4^{\text {th }}\right.$ at transplanting, $1 / 2$ at active stage of vegetative growth, and $1 / 4^{\text {th }}$ at the start of bulbing). Phosphorus in the form of TSP was applied to all plots equally at $92 \mathrm{~kg}_{2} \mathrm{O}_{5}$ $\mathrm{ha}^{-1}$. All the required amount of TSP was applied in band just before transplanting at the depth of $10 \mathrm{~cm}$ below the soil level of positioning the roots of the seedlings.

At physiological maturity when $70 \%$ of their leaves senesced, plants were harvested and used for determining yield components [13]. Plants in the border rows as well as those at both ends of each harvested row were left to avoid edge effects. All other cultural practices such as weeding, supplementary irrigation control of pests and diseases were performed as per the regional recommendations.

\subsection{Statistical Analysis}

Data were subjected to analysis of variance using SAS Statistical Software package. Means that differed significantly were separated using the Least Significant Difference (LSD) test procedure at $5 \%$ level of significance. Pearson Correlation coefficients were determined for parameters using the same software.

\section{Results and Discussion}

The statistical analysis in Table 1 shows that average fresh bulb weight $\left(\mathrm{g} \mathrm{plant}^{-1}\right)$, bulb diameter $(\mathrm{cm})$ and dry total biomass $\left(\mathrm{g}\right.$ plant $^{-1}$ ) show significant difference at $5 \%$ significant level among treatments.

\subsection{Average fresh bulb weight}

When the rate of nitrogen was increased from 0 to $50 \mathrm{~kg} \mathrm{~N}$ $\mathrm{ha}^{-1}$, bulb fresh weight increased per plant by $9.0 \%$ (Table 1). Increasing the rate of nitrogen from 50 to $100 \mathrm{~kg} \mathrm{~N}$ ha-1 increased the bulb fresh weight further by $12 \%$. However, increasing the rate of $\mathrm{N}$ from 100 to $150 \mathrm{~kg} \mathrm{~N}$ ha-1 decreased bulb fresh weight significantly by $5 \%$. This result was similar with [17] who reported significant increases in the bulb weight of onion due to increased nitrogen application. The significant decline of fresh bulb weight in response to increasing rate of nitrogen from 100 to $150 \mathrm{~kg} \mathrm{~N}$ ha-1 may be attributed to overdose or supra optimal supply of the nutrient which may have led to excessive growth of vegetative parts at the expense of growth and development of bulbs. Increasing the intra row spacing from 4 to $6 \mathrm{~cm}$, increased bulb fresh weight by $16 \%$. Further widening the intra row spacing from 6 to $8 \mathrm{~cm}$ did not change bulb fresh weight. However, when the intra row spacing was widened to $10 \mathrm{~cm}$, then bulb fresh weight was increased by $7.45 \%$.

\subsection{Bulb diameter}

The statistical analysis in Table 1 revealed that significant difference at 5\% significant level among treatments. Increasing nitrogen rate from $50 \mathrm{~kg}$ to $100 \mathrm{~kg} \mathrm{~N} \mathrm{ha}^{-1}$ significantly increased bulb diameter by $5 \%$. However, increasing nitrogen rate from 0 to $50 \mathrm{~kg} \mathrm{~N}^{-1}$ and 100 to $150 \mathrm{~kg} \mathrm{~N}^{-1}$ did not affect bulb diameter of onion. $\mathrm{N}$ rate significantly increased bulb diameter by about $16 \%$ due to $150 \mathrm{~kg} \mathrm{~N} \mathrm{ha}^{-1}$ in reference to the control, which may be due to the increase in dry matter production and allocation to the bulb. This was in agreement with the results of [18] who reported a significant increase in the diameter of bulbs due to the application of $\mathrm{N}$ up to $120 \mathrm{~kg} \mathrm{ha}^{-1}$. Also it was found significantly increased bulb diameter by about $12 \%$ due to $\mathrm{N}$ $138 \mathrm{~kg} \mathrm{ha}^{-1}$ fertilization [19]. Similarly bulb diameter was significantly influenced by intra row spacing where $6 \mathrm{~cm}$ gave significantly the highest bulb diameter of $5.673 \mathrm{~cm}$ compared with the narrow intra row spacing of $4 \mathrm{~cm}$ which gave $4.826 \mathrm{~cm}$. This may be due to less competition for resources in the case of wider plant spacing.

Table 1: The main effects of nitrogen and intra row spacing on average bulb weight, bulb diameter, dry total biomass yield and shoot dry weight

\begin{tabular}{|c|c|c|c|c|}
\hline $\begin{array}{c}\mathrm{N} \\
\left(\mathrm{kg} \mathrm{ha}^{-1}\right)\end{array}$ & $\begin{array}{c}\text { Average } \\
\text { bulb weight }^{\left(\mathrm{g} \mathrm{plant}^{-1}\right)}\end{array}$ & $\begin{array}{c}\text { Bulb } \\
\text { Diameter } \\
(\mathrm{cm})\end{array}$ & $\begin{array}{c}\text { Dry total } \\
\text { biomass } \\
\left(\mathrm{g} \mathrm{plant}^{-1}\right)\end{array}$ & $\begin{array}{c}\text { Shoot dry } \\
\text { weight }(\mathrm{g})\end{array}$ \\
\hline 0 & $70.667 \mathrm{c}$ & $4.907 \mathrm{~b}$ & $47.228 \mathrm{~d}$ & $18.963 \mathrm{c}$ \\
\hline 50 & $77.250 \mathrm{~b}$ & $5.358 \mathrm{ab}$ & $59.654 \mathrm{c}$ & $23.195 \mathrm{~b}$ \\
\hline 100 & $86.500 \mathrm{a}$ & $5.628 \mathrm{a}$ & $65.743 \mathrm{~b}$ & $25.412 \mathrm{a}$ \\
\hline 150 & $82.333 \mathrm{~b}$ & $5.693 \mathrm{a}$ & $72.756 \mathrm{a}$ & $26.691 \mathrm{a}$ \\
\hline F-test & $* *$ & $*$ & $* *$ & $* *$ \\
\hline \multicolumn{5}{|c|}{ Intra row Spacing (cm) } \\
\hline 4 & $69.333 \mathrm{c}$ & $4.826 \mathrm{~b}$ & $53.843 \mathrm{~d}$ & $16.689 \mathrm{~d}$ \\
\hline 6 & $80.250 \mathrm{~b}$ & $5.673 \mathrm{a}$ & $58.518 \mathrm{c}$ & $21.343 \mathrm{c}$ \\
\hline 8 & $80.583 \mathrm{~b}$ & $5.443 \mathrm{a}$ & $64.204 \mathrm{~b}$ & $25.80 \mathrm{~b}$ \\
\hline 10 & $86.583 \mathrm{a}$ & $5.643 \mathrm{a}$ & $68.815 \mathrm{a}$ & $30.428 \mathrm{a}$ \\
\hline F-test & $* *$ & $*$ & $* *$ & $* *$ \\
\hline LSD(0.05) & 4.943 & 0.519 & 3.298 & 2.1678 \\
CV (\%) & 7.486 & 11.543 & 6.449 & 11.034 \\
\hline
\end{tabular}

\section{Volume 5 Issue 10, October 2016} www.ijsr.net 


\section{International Journal of Science and Research (IJSR) \\ ISSN (Online): 2319-7064 \\ Index Copernicus Value (2013): 6.14 | Impact Factor (2015): 6.391}

Means sharing a common letter are not significantly different at 5\%level of significance Ns = non significant. *, ** shows

significance at 5\% and $1 \%$ level of significance respectively

\subsection{Dry total biomass yield}

Dry total biomass yield of the onion crop increased linearly with the increases in the rate of nitrogen application (Table 1). As the rate of nitrogen application increased from 0 to 50 $\mathrm{kg} \mathrm{ha}^{-1}$, dry total biomass yield increased significantly by 26 $\%$. Increased application of nitrogen from $50 \mathrm{~kg} \mathrm{~N}^{-1}$ to $100 \mathrm{~kg} \mathrm{~N} \mathrm{ha}^{-1}$ further increased dry total biomass yield by 10 $\%$. When the rate of nitrogen was further raised to $150 \mathrm{~kg} \mathrm{~N}$ $\mathrm{ha}^{-1}$ from $100 \mathrm{~kg} \mathrm{~N} \mathrm{ha}^{-1}$, dry total biomass yield increased by $11 \%$. A previous field research also showed that application of $\mathrm{N}$ fertilizer at the rate of $150 \mathrm{~kg} \mathrm{~N} \mathrm{ha}^{-1}$ increased dry total biomass [18]. The marked increase in total biomass yield in response to the increased rate of $\mathrm{N}$ application could be attributed to an increased photosynthetic area in response to fertilization that enhanced assimilate production and partitioning to the bulbs.

Widening the inter-row spacing from $4 \mathrm{~cm}$ up to $10 \mathrm{~cm}$ linearly increased the dry total biomass yield of the crop. Widening the spacing from 4 to $6 \mathrm{~cm}$ was increased dry total biomass yield by $9 \%$. Further widening the intra row spacing from 6 to $8 \mathrm{~cm}$ increased the dry total biomass yield by $10 \%$. When the intra row spacing was further widened to $10 \mathrm{~cm}$, dry total biomass yield increased further by $7 \%$. The dry total biomass yield of plants grown at the intra row spacing of $10 \mathrm{~cm}$ exceeded the dry total biomass yield of plants grown at the spacing of $4 \mathrm{~cm}$ by $28 \%$. This result demonstrates that plants grown at the widest spacing produced the highest dry total biomass yield possibly due to less stiff competition among them for growth factors.

\subsection{Shoot dry weight}

The analysis of variance of shoot dry weight showed that the main effects of nitrogen and intra-row spacing highly significantly $(\mathrm{P}<0.01)$ influenced shoot dry weight of onion plants (Table 1). In response to increasing the rate of nitrogen from 0 to $50 \mathrm{~kg} \mathrm{~N} \mathrm{ha}{ }^{-1}$, shoot dry matter yield increased by $22 \%$. Increasing the rate of nitrogen from 50 to $100 \mathrm{~kg} \mathrm{~N} \mathrm{ha}^{-1}$ increased the shoot dry matter yield further by $10 \%$. However, increasing the rate of nitrogen beyond 100 $\mathrm{kg} \mathrm{N}$ ha $^{-1}$ did not change shoot dry matter yield. The increase in shoot dry matter yield in response to increasing the rate of nitrogen from 0 to $100 \mathrm{~kg} \mathrm{~N} \mathrm{ha}^{-1}$ amounted to $34 \%$. This result shows that nitrogen enhanced assimilate production and dry matter accumulation in onion plants. The result is in accord with that of [18] who reported that, higher shoot dry weight was recorded when nitrogen supply was raised up from nil to $150 \mathrm{~kg} \mathrm{ha}^{-1}$.

Similarly, shoot dry weight significantly increased with increasing intra row spacing. Widening the intra-row spacing, from 4 to $6 \mathrm{~cm}$, increased shoot dry matter yield by about 28\%. Further widening the intra-row spacing from 6 to $8 \mathrm{~cm}$ again increased shoot dry matter yield by $21 \%$. When the intra-row spacing was widened to $10 \mathrm{~cm}$, the shoot dry matter yield increased further by $10 \%$. The shoot dry matter yield of plants grown at the intra-row spacing of $10 \mathrm{~cm}$ exceeded the shoot dry matter yields of plants grown at the spacing of $4 \mathrm{~cm}$ by $82 \%$ (Table 1 ). The result showed that plants grown at the widest spacing produced the highest shoot dry matter yield possibly due to less completion among them for growth factors such as light, water and mineral nutrients. At wider spacing, due to less competition for light and other resources, plants apparently accumulated more shoot dry weight. This may be due to the fact that the crop plants should cover the soil to intercept maximum sunlight to produce higher dry matter as the intercepted solar radiation and dry matter production are directly related.

\subsection{Marketable Yield:}

Statistical analysis shows that marketable yield $\left(\mathrm{t} \mathrm{ha}^{-1}\right)$ was significance difference among treatments at 5\% level of significance (Table 2).The highest marketable yield was recorded at $100 \mathrm{~kg} \mathrm{~N} \mathrm{ha}^{-1}\left(31.455 \mathrm{t} \mathrm{ha}^{-1}\right)$. Increasing the rate of $\mathrm{N}$ from 0 to $50 \mathrm{~kg} \mathrm{~N}^{-1}$ markedly increased marketable fresh bulb yield by $45 \%$. Increasing the rate of $\mathrm{N}$ from 50 to $100 \mathrm{~kg} \mathrm{~N} \mathrm{ha}{ }^{-1}$ increased the marketable fresh bulb yield further by $30 \%$. However, increasing the rate of $\mathrm{N}$ from 100 to $150 \mathrm{~kg} \mathrm{~N}^{-1}$ tended to decrease marketable fresh bulb yield by $5 \%$. Thus, $100 \mathrm{~kg} \mathrm{~N}^{-1}$ resulted in the production of optimum fresh marketable bulb yield, and there is no need to increase the rate of the nutrient above this rate. An experiment carried out on onions using $\mathrm{N}$ rates ranging from 0 to $180 \mathrm{~kg} \mathrm{ha}^{-1}$ and found that the highest yield and percentage of marketable bulb production occurred in response to $60 \mathrm{~kg} \mathrm{~N}^{-1}$ while, $180 \mathrm{~kg} \mathrm{~N}^{-1}$ hasulting in yield that was even lower than that of the treatment without $\mathrm{N}$ [20] .

Widening the intra row spacing from 4 to $6 \mathrm{~cm}$ significantly increased the fresh marketable bulb yield by $10 \%$. However, widening the intra row spacing to the higher levels did not change marketable fresh bulb yield. This result shows that plants grown at the wider spacing of 6,8 , and 10 $\mathrm{cm}$ produced the highest fresh marketable bulb yields due to less competition than plants grown at the narrowest intra row spacing of $4 \mathrm{~cm}$.

\subsection{Unmarketable yield}

Unmarketable fresh bulb yields decreased (1.81 to 1.39 t ha ${ }^{1}$ ) with the increase in the rate of $\mathrm{N}$ application (Table 2). Thus, the highest unmarketable fresh bulb yields were obtained from plots that received 0 and $50 \mathrm{~kg} \mathrm{~N} \mathrm{ha}^{-1}$. The smallest unmarketable fresh bulb yields were obtained from plots that received 100 and $150 \mathrm{~kg} \mathrm{~N} \mathrm{ha}^{-1}$. This shows that $\mathrm{N}$ improves marketability or decreases unmarketable of onion bulbs through the positive role it plays in increasing average bulb fresh weight.

Widening the intra row spacing tended to decrease the yield of unmarketable bulbs of the crop (Table 2). Only plants grown at the intra row spacing of $4 \mathrm{~cm}$ and $8 \mathrm{~cm}$ differed significantly in the yield of unmarketable bulbs. Thus, plants grown at the spacing of $4 \mathrm{~cm}$ produced $27.5 \%$ more unmarketable bulb yields than at the intra row spacing of 8 $\mathrm{cm}$. This shows that growing onion at the narrow intra row spacing of $4 \mathrm{~cm}$ produced the highest unmarketable bulb yields followed by intra row spacing of $6 \mathrm{~cm}$. Small sized

\section{Volume 5 Issue 10, October 2016}




\section{International Journal of Science and Research (IJSR) \\ ISSN (Online): 2319-7064 \\ Index Copernicus Value (2013): 6.14 | Impact Factor (2015): 6.391}

and misshaped bulbs may contribute to the amount of unmarketable bulb yield due to the stiff inter plant competition for growth factors. For the widest intra row spacing, production of considerable numbers of too large bulbs may contribute to the amount unmarketable fresh bulb yield due to low inter plant competition for growth factors.

Table 2: The main effects of nitrogen and intra row spacing on marketable,unmarketable, total fresh bulb yields and Total Soluble Solids

\begin{tabular}{|c|c|c|c|c|}
\hline $\mathrm{N}\left(\mathrm{kg} \mathrm{ha}^{-1}\right)$ & $\begin{array}{c}\text { Marketable yield } \\
\left(\mathrm{t} \mathrm{ha}^{-1}\right)\end{array}$ & $\begin{array}{c}\text { Unmarketable } \\
\text { yield }\left(\mathrm{t} \mathrm{ha}^{-1}\right)\end{array}$ & $\begin{array}{c}\text { Total yield } \\
\left(\mathrm{t} \mathrm{ha}^{1}\right)\end{array}$ & $\begin{array}{c}\text { Harvest } \\
\text { Index (\%) }\end{array}$ \\
\hline 0 & $16.588 \mathrm{c}$ & $1.72 \mathrm{ab}$ & $18.31 \mathrm{c}$ & $73.033 \mathrm{c}$ \\
\hline 50 & $24.114 \mathrm{~b}$ & $1.81 \mathrm{a}$ & $25.93 \mathrm{~b}$ & $74.535 \mathrm{cb}$ \\
\hline 100 & $31.455 \mathrm{a}$ & $1.39 \mathrm{~b}$ & $32.84 \mathrm{a}$ & $75.904 \mathrm{ab}$ \\
\hline 150 & $29.669 \mathrm{a}$ & $1.43 \mathrm{~b}$ & $31.10 \mathrm{a}$ & $77.642 \mathrm{a}$ \\
\hline F-test & $* *$ & $*$ & $* *$ & $*$ \\
\hline \multicolumn{5}{|c|}{ Intra row Spacing (cm) } \\
\hline 4 & $24.23 \mathrm{~b}$ & $1.81 \mathrm{a}$ & $26.03 \mathrm{~b}$ & $81.803 \mathrm{a}$ \\
\hline 6 & $26.72 \mathrm{a}$ & $1.60 \mathrm{ab}$ & $28.32 \mathrm{a}$ & $76.205 \mathrm{~b}$ \\
\hline 8 & $25.43 \mathrm{ab}$ & $1.42 \mathrm{~b}$ & $26.85 \mathrm{ab}$ & $72.979 \mathrm{c}$ \\
\hline 10 & $25.45 \mathrm{ab}$ & $1.52 \mathrm{ab}$ & $26.97 \mathrm{ab}$ & $70.128 \mathrm{~d}$ \\
\hline F-test & $*$ & $*$ & $*$ & $* *$ \\
\hline LSD (0.05) & 2.097 & 0.360 & 2.156 & 2.716 \\
CV (\%) & 9.882 & 27.196 & 9.563 & 4.327 \\
\hline \multicolumn{5}{|c|}{}
\end{tabular}

Means sharing a common letter are not significantly different at 5\%level of significance Ns=non significant.

*, ** shows significance at $5 \%$ and $1 \%$ level of significance respectively

\subsection{Total bulb yield}

From Table 2, similar trend to marketable yield was observed. Increasing the rate of $\mathrm{N}$ from 0 to $50 \mathrm{~kg} \mathrm{~N}^{-1}$ markedly increased total bulb yield by $42 \%$. Increasing the rate of nitrogen from 50 to $100 \mathrm{~kg} \mathrm{~N} \mathrm{ha}^{-1}$ increased the total bulb yield further by $27 \%$. However, similar to the marketable bulb yield, increasing the rate of $\mathrm{N}$ from 100 to $150 \mathrm{~kg} \mathrm{~N} \mathrm{ha}{ }^{-1}$ tended to decrease total bulb yield by $5 \%$. Increasing the rate of $\mathrm{N}$ from nil to $100 \mathrm{~kg} \mathrm{~N} \mathrm{ha}^{-1}$ significantly increased total fresh bulb yield by $79 \%$. Thus, similar to the marketable fresh bulb yield, $100 \mathrm{~kg} \mathrm{~N}$ ha $^{-1}$ resulted in the production of optimum total bulb yield (32.84 $\mathrm{t} \mathrm{ha}^{-1}$ ). Therefore; further addition of nitrogen doses above $100 \mathrm{~kg} \mathrm{ha}^{-1}$ did not increase yield of the onion crop.

Several researchers reported similar results. It was also found that increase in $\mathrm{N}$ dose up to $100 \mathrm{~kg} \mathrm{~N}^{-1}$ resulted in increased yield of onion bulbs but further increase of nitrogen to $150 \mathrm{~kg} \mathrm{~N}^{-1}$ did not significantly increase the yield [21]. A report indicated that maximum yield of onion bulbs was obtained from application of mineral $\mathrm{N}$ fertilizer at the rate of $100 \mathrm{~kg} \mathrm{~N} \mathrm{ha}^{-1}$ [17]. Similarly, [22] reported that yield incensement in the range of 0 to $150 \mathrm{~kg} \mathrm{ha}^{-1}$ after which it decreased.

Increasing the intra row spacing from 4 to $6 \mathrm{~cm}$ significantly increased the total fresh marketable bulb yield by $9 \%$ (Table 2). However, increasing the intra row spacing to all higher spacing did not change total bulb yield. This result shows that plants grown at intra row spacing of $6 \mathrm{~cm}$ produced the higher mean total bulb yields. [23] (1991) also reported that, closer intra row spacing of $5 \mathrm{~cm}$ increased bulb yield by $7.6 \%$ over $10 \mathrm{~cm}$. Similarly, [24] also found that in Bombay
Red at the intra row spacing of $4 \mathrm{~cm}$ produced the highest yield compared with $10 \mathrm{~cm}$ intra row spacing at the rift valley of Ethiopia. However, experimental result showed that optimum yield at $10 \mathrm{~cm} \times 20 \mathrm{~cm}$ spacing after compared with $12 \times 20 \mathrm{~cm}$ and $6 \times 20 \mathrm{~cm}$. Such difference may be difference in soil condition, variety of onion used or agro ecological variability [25].

\subsection{Harvest index}

Harvest index increased with the increase in the rate of nitrogen application (Table 2). The highest harvest index, (77.642 \%), was produced at the application of $150 \mathrm{~kg} \mathrm{~N} \mathrm{ha}^{-}$ ${ }^{1}$, which increased the parameter by about $6 \%$ compared with the control. This indicates that application of higher amounts of $\mathrm{N}$ is important for onion to produce more assimilates for growth, development, and bulb production. Similarly, [19] indicated that $\mathrm{N}$ application improved harvest index in onion by increasing both bulb dry weight and total biomass yield.

Increasing the intra row spacing of onion, linearly and significantly decreased harvest index (Table 2). Widening the intra row spacing from 4 to 6,8 , and $10 \mathrm{~cm}$ significantly reduced harvest index by 7,4 , and $4 \%$, respectively in the order mentioned here. The harvest index of plants grown at the narrowest intra row spacing of $4 \mathrm{~cm}$ exceeded the harvest index of plants grown at the widest intra row spacing of $10 \mathrm{~cm}$ by $14 \%$. This result demonstrates that bulbs of plants grown at the narrowest spacing were compact and had more dry matter relative to the smaller biomass produced due to stiffer competition between plants. On the other hand, bulbs produced by plants grown at the widest spacing produced higher bulb dry biomass yield but also that of above ground dry biomass yield due to relatively sufficient growth factors for photo-assimilation, thereby reducing the relative ratio of bulb dry matter to the dry matter of total biomass, which is harvest index.

\section{Conclusion}

Lack of improved production practices have been the major bottlenecks of onion productivity in northern Ethiopia particularly at Shire area. Keeping optimum intra row spacing and $\mathrm{N}$ fertilizer, helps to maintain higher yield and also to get marketable bulb size. Optimum marketable yield was found from plots that were planted using $6 \mathrm{~cm}$ intra row spacing and application of $100 \mathrm{~kg} \mathrm{ha}^{-1} \mathrm{~N}$ compared with other treatments. Therefore, it could be concluded that Onion Bombay Red cultivar should be planted during the rainy season at optimum spacing of $6 \mathrm{~cm} \times 20 \mathrm{~cm}$ with application of $100 \mathrm{~kg} \mathrm{~N} \mathrm{ha}^{-1}$ at Shire area to attain maximum yield.

\section{Acknowledgement}

Special thanks to The Well Foundation Organization in Shire for allowing me to use their farm and facility. 


\section{International Journal of Science and Research (IJSR) \\ ISSN (Online): 2319-7064 \\ Index Copernicus Value (2013): 6.14 | Impact Factor (2015): 6.391}

\section{References}

[1] Welbaum.G.E., 2015. Vegetable Production and Practices. Virginia Tech University, USA http://www.cabi.org 486pp.

[2] Rabinowitch H.D. and Currah L. (eds.), 2002. Allium Crop Science: Recent advances. CABI Publishing. Wallingford, UK. 515 pp.

[3] Randle, W.M. and Ketter, C.A. 1998. Pungency assessment in onions. Proceedings of the19 workshop conference of the Association for Biology Laboratory Education (ABLE). pp177-196. http://www.zoo.utoronto.ca

[4] Grubben, G. J. H. \& Denton, O. A. (eds). 2004. Plant resources of Tropical Africa 2. Nordic Journal of Botany, 23(3): $298 . \quad$ doi:10.1111/j.17561051.2003.tb00397.x

[5] CSA (Central Statistics Authority). 2011. Agriculture sample survey. September to 2010. Report on Area and production of major Crops (Private peasant holdings, meher season). Bulletin. Vol. I. Addis Ababa, Ethiopia.

[6] FAO STAT Data. 2012. http;//www.fao.org. Accessed on February 132013.

[7] Gupta, R.P., Sharma, V.P., Singh, D.K., and Srivastav, K.J. 1999. Effect of organic manures and inorganic fertilizers on growth, yield and quality of onion variety Agrifound Dark Red. News Letter National Horticultural Research and Development Foundation India. 19(2-3):7-11.

[8] Lemma Dessalegn and Shimeles Aklilu. 2003. Research Experiences in Onion production. Research Report No. 55. Ethiopia Agricultural Research Organization. Addis Ababa.

[9] Zubelidia, A. and Gases, J.L. 1977. Effect of spacing and Number of stem on the Earliness and Total yield of Tomato cultivars. Product. Veg. 7: 73.

[10] FAO. 1995. STAT Data. Production yearbook. Italy, Rome.

[11] Jilani, M. S. 2004. Studies on the management strategies for bulb and Seed production of different cultivars of onion (Allium cepa L.). a dissertation submitted to NWFP. Agriculture University, Peshawar, Pakistan. http://eprints.hec.gov.pk/1013/1/744.html.htm

[12] Lemma Dessalegn. 2004. Onion Production Pamphlet (Amharic version). EARO, Melkassa Research Center. Ethiopia.

[13] EIAR (Ethiopian institutes of Agricultural Research). 2004. Directory of released crop Varieties and their recommended cultural practices. Addis Ababa, Ethiopia.

[14] Nikus, O. and Fikre Mulugeta. 2010. Onion seed Production Techniques. A Manual for Extension Agents and Seed Producers. FAO. Crop Diversification \& Marketing Development Project. Asella, Ethiopia.

[15] Finneran Niall. 2005. The Archeological Landscape of the Shire Region, Western Tigray, Ethiopia. In: Annales d'Ethiopie. Volume 21, année pp. 7-29; doi: 10.3406/ethio.2005.1091http://www.persee.fr/doc/ethio _0066-2127_2005_num_21_1_1091

[16] Yayneshet, T., 2010. Feed resources available in Tigray region, northern Ethiopia for production of export quality meat and Livestock. Addis Ababa. www.igad- data.org/livestock-production/doc/feed-resourcesassessment-in-tigray-regional-state-ethiopia.

[17] Khan, H.M. Igbal, Ghaffoor, A. and Wasseem, K. 2002. Effect of various plant spacing and different levels of nitrogen on the growth and yield of onion (Allium cepa L). Journal of Biological Science. 2;545-547

[18] Nasreen, S, Haque, M.M., Hossain, MA. and Farid ATM .2007. Nutrient uptake and yield of onion as influenced by nitrogen and sulphur fertilization. Bangladesh J. Agric. Res.32(3): 413-420

[19] Abdissa Yohannes, Tekalign Tsegaw and Pant, L.M. 2011. Growth, bulb yield and quality of Onion (Allium cepa L.) as influenced by nitrogen and phosphorus fertilization on vertisol I. growth attributes biomass production and bulb yield. African Journal of Agricultural Research Vol. 6(14), pp.3252-3258. http://www.academicjournals.org/AJAR.

[20] Cizauskas, A., Viskelis, P., Dris, R. and Oladele, OI. 2003. Influence of nitrogen rates on onion yield quality and storability. Moor Journal of Agricultural Research. ISSN: $\quad$ 1595-4153.V0l.4(1) 2003: 858.www.ajol.info/index.php/mjar/article/view/31758

[21] Aliyu, U., M.D. Magaji, A. Singh and S.G. Mohammed, 2007. Growth and Yield of Onion (Allium cepa L.) as Influenced by Nitrogen and Phosphorus Levels. International Journal of Agricultural Research, 2: 937-944.DOI: 10.3923/ijar.2007.937.944.URL: http://scialert.net/abstract/?doi=ijar.2007.937.944.

[22] Brewester, J.L.1994. Onions and other vegetable Alliums. CAB International. Wallingford. UK. p. 236.

[23] Mohamed, E.N.O.M. 1991. Effect of plant population and nutrition on yield and quality of onion in Kassala, Sudan.

http://arcsudan.sd/arc/conferences/meeting37/pdf/5.pdf

[24] Geremew A., Teshome A., Kasaye T. and Amenti C., 2009. Effect of intra-row spacing on yield of three onion (Allium cepa l.) Varieties at Adami Tulu Agricultural Research center (mid rift valley of Ethiopia). Journal of Horticulture and Forestry. Vol. 2(1) pp. 007011.http://www.academicjournals.org/jhfJanuary. (accessed 22.01.15).

[25] Viloria, A., Arteaga, L., Díaz, L. and Delgado, D. 2003. Effect of N-P-K fertilization and planting distance on onion (Allium cepa L.) yield. Bioagro. 15:129-133.

[26] Russo, V.M. 2008. Plant Density and Nitrogen Fertilizer Rate on Yield and Nutrient Content of Onion Developed from Greenhouse grown Transplants. Hort. science 43(6):1759-1764. http://hortsci.ashspublications.org/content/43/6/1759.ful l.pdf.

\section{Author Profile}

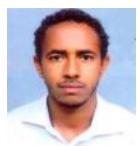

Kiros Gebretsadik received his B.Sc in Plant Science from Debub (now Hawassa) University and M.Sc. degrees in Horticulture from Haramaya University in 2006 and 2013, respectively. During 2006-2010, he worked at Shire Agricultural TVET College. Now he is Lecturer, Research and Community service officer at Aksum University, Shire Campus. 